\title{
Korelasi Keterampilan Membaca Pemahaman Teks Deskripsi dengan Keterampilan Menulis Teks Deskripsi Siswa Kelas VII SMP Negeri 1 Bonjol
}

\author{
Dina Zahara ${ }^{* 1}$, Afnita ${ }^{2}$ \\ Universitas Negeri Padang ${ }^{1,2}$ \\ Corresponding email: dinazahara05@gmail.com*
}

\begin{abstract}
The purpose of this study was to determine the relationship between the reading comprehension skills of the descriptive text and the writing skills of the seventh grade students of SMP Negeri 1 Bonjol. This research used quantitative research using a descriptive correlational design. In this study, there were two variables, namely the $X$ variable and the $Y$ variable. The $X$ variable was the reading comprehension skill, while the $Y$ variable was the description text writing skill. The research instruments were objective tests and performance tests. The data of this study are the results of the reading comprehension skills test and the results of the descriptive text writing skills test. The test results were compared using the t-test formula to determine the correlation between the reading comprehension skills and the descriptive text writing skills of the seventh grade students of SMP Negeri 1 Bonjol. There are three results in this study. First, the reading skills of grade VII students of SMP Negeri 1 Bonjol are in good qualifications with an average score of 81.65. Second, the writing skills of the seventh grade students of SMP Negeri 1 Bonjol are in good qualifications with an average score of 78.58. Third, based on the results of the t-test, it can be concluded that there is a relationship between comprehension reading skills and the descriptive text writing skills of seventh grade students of SMP Negeri 1 Bonjol.
\end{abstract}

Keywords: correlation, reading comprehension skills, descriptive text writing skills

\begin{abstract}
Abstrak
Tujuan penelitian ini adalah untuk mengetahui hubungan antara keterampilan membaca pemahaman teks deskripsi dengan keterampilan menulis teks deskripsi siswa kelas VII SMP Negeri 1 Bonjol. Penelitian ini menggunakan penelitian kuantitatif dengan menggunakan desain deskriptif korelasional. Dalam penelitian ini terdapat dua variabel, yaitu variabel $X$ dan variabel $Y$. Variabel $X$ adalah keterampilan membaca pemahaman sedangkan variabel $\mathrm{Y}$ adalah keterampilan menulis teks deskripsi. Instrumen penelitian ini adalah tes objektif dan tes kinerja. Data penelitian ini adalah hasil tes keterampilan membaca pemahaman dan hasil tes keterampilan menulis teks deskripsi. Hasil tes dibandingkan dengan menggunakan rumus t-tes untuk menentukan korelasi keterampilan membaca pemahaman dengan keterampilan menulis teks deskripsi siswa kelas VII SMP Negeri 1 Bonjol. Terdapat tigas hasil dalam penelitian ini ialah pertama, keterampilan membaca pemahaman siswa kelas VII SMP Negeri
\end{abstract}


1 Bonjol berada dalam kualifikasi baik dengan nilai rata-rata 81,65. Kedua, keterampilan menulis teks deskripsi siswa kelas VII SMP Negeri 1 Bonjol berada pada kualifikasi baik dengan nilai rata-rata 78,58. Ketiga, berdasarkan hasil uji-t dapat disimpulkan bahwa ada hubungan antara keterampilan membaca pemahama dengan keterampilan menulis teks deskripsi siswa kelas VII SMP Negeri 1 Bonjol.

Kata kunci: korelasi, keterampilan membaca pemahaman teks deskipsi, keterampilan menulis teks deskripsi

\section{PENDAHULUAN}

Menulis merupakan salah satu keterampilan berbahasa. Keterampilan menulis sangat penting dalam kehidupan, baik dalam pendidikan maupun dalam masyarakat. Dalam menulis, siswa harus mengetahui apa yang akan ditulis dan harus menguasai kosakata untuk menjadikan sebuah tulisan (Rinawati, 2020). Dengan rajin menulis dapat menjadikan siswa lebih kreatif dan sebaliknya jika malas menulis maka akan menjadikan siswa sulit mengungkapkan ide-ide atau gagasan ke dalam bentuk tulisan. Oleh karena itu, siswa harus menguasai pembelajaran bahasa Indonesia terutama mampu menulis sesuai kaidah, menguasai kosakata, dan menguasai Ejaan Bahasa Indonesia (EBI). Pada pembelajaran bahasa Indonesia terdapat pembelajaran berbasis teks. Pembelajaran berbasis teks pada siswa kelas VII SMP diantaranya ialah keterampilan menulis teks deskripsi.

Pembelajaran bahasa Indonesia memiliki peranan penting bagi siswa. Pembelajaran ini bertujuan agar siswa memiliki kemampuan berkomunikasi secara efektif dan efisien sesuai dengan etika yang berlaku (Kusumaswarih, 2018). Selain itu, pembelajaran ini bertujuan untuk melatih siswa terampil berbahasa dengan menuangkan ide dan gagasannya secara kreatif dan kritis (Noermanzah, 2013). Mata Pelajaran Bahasa Indonesia dalam Kurikulum 2013 secara umum bertujuan agar peserta didik mampu menyimak, membaca, memirsa, berbicara, menulis, dan menyajikan. Dalam kurikulum 2013, Mata Pelajaran Bahasa Indonesia diorientasikan pada pembelajaran berbasis teks. Pembelajaran berbasis teks lebih menekankan pada siswa untuk memahami dan memproduksi teks, baik lisan maupun tulis dalam berbagai konteks (Umaya, 2017). Aspek berbahasa yang termasuk ke dalam keterampilan memahami adalah menyimak, membaca, dan memirsa, sedangkan yang termasuk ke dalam keterampilan memproduksi adalah berbicara, menulis, dan menyaji. Salah satu aspek keterampilan memproduksi ini yang harus dikuasai oleh siswa adalah keterampilan menulis. Keterampilan menulis sangat penting bagi siswa karena dengan menulis siswa dapat menuangkan ide, gagasan, dan pemikirannya ke dalam bahasa tulis. Selain itu, keterampilan menulis menuntut siswa agar lebih kreatif dalam menata pola pikirnya. Dengan menulis, siswa terlatih dalam mengungkapkan gagasannya agar tulisan yang dihasilkan dapat diterima oleh pembaca. Keterampilan menulis juga menuntut siswa untuk mempunyai pengetahuan yang luas, misalnya kaidah-kaidah dalam menulis, menguasai kosakata, dan sebagainya (Noermanzah, 2018).

Menulis adalah suatu proses kreatif menuangkan gagasan, ide, pikiran, perasaan dalam bentuk bahasa tulis yang tujuannya untuk memberitahukan, meyakinkan, dan menghibur pembaca sehingga dapat memhami tulisan yang ditulis dengan baik (Muttaqillah, 2019). Menurut Tarigan (2008) menulis merupakan suatu keterampilan berbahasa yang dipergunakan untuk berkomunikasi secara tidak 
langsung. Fungsi menulis antara lain untuk mengemukakan pendapat, ide, atau mengekspresikan pikiran. Dalam pembelajaran menulis teks deskripsi, siswa diharapkan mampu mengembangkan ide, gagasan, dan pikiran dalam tulisan yang menggambarkan suatu obyek, tempat, atau peristiwa tertentu kepada pembaca secara jelas dan terperinci (Haryati, 2018; Karto dkk., 2019). Akan tetapi kenyataan di sekolah menunjukkan bahwa siswa belum mampu menulis teks deskripsi sesuai yang diharapkan. Hal tersebut disebabkan permasalahan yang dihadapi siswa dalam menulis terutama dalam menuangkan gagasan sesuai dengan ciri-ciri teks deskripsi.

Menurut Agustina (dalam Anggriani, 2016) untuk mendapatkan informasi dalam suatu bacaan, diperlukan pemahaman terhadap suatu bacaan, sehingga dalam membaca banyak cara yang dilakukan. Salah satunya adalah membaca pemahaman. Membaca pemahaman yaitu suatu kegiatan membaca untuk memperoleh informasi dari bahan bacaan dan memahami makna yang tersirat dari bacaan secara menyeluruh (Manullang \& Lubis, 2017; Sari dkk., 2020; Hermanudin dkk., 2019).

Keterampilan menulis dan keterampilan membaca pemahaman memiliki hubungan yang erat (Novia dkk., 2017). Oleh sebab itu, jika siswa rajin membaca maka akan mudah untuk menuangkan segala ide kedalam tulisannya karena mempunyai pengetahuan yang luas. Menurut Sari dkk. (2018) keterampilan membaca pemahaman sangat memberi sumbangan besar terhadap keterampilan menulis siswa. Hal itu sependapat dengan Abidin (dalam Khasanah \& Cahayani, 2016), bahwa pembelajaran dapat diartikan sebagai serangkaian aktivitas yang dilakukan siswa untuk mencapai keterampilan membaca. Dengan adanya pembelajaran membaca dapat melibatkan seluruh kegiatan berpikir siswa dalam memahami dan memproduksi sebuah teks.

Dengan siswa memiliki kemampuan membaca pemahaman diprediksi akan mampu juga menulis teks deskripsi. Semi (2003) dan Amrolani dkk. (2014) menyatakan bahwa teks deskripsi adalah tulisan yang tujuannya memberikan perincian atau detail tentang objek sehingga dapat memberi pengaruh pada sensitivitas dan imajinasi pembaca atau pendengar, bagaikan mereka ikut melihat, mendengar, merasakan, atau mengalami langsung objek tersebut. Senada dengan pendapat tersebut, Prayitni (2014) menjelaskan bahwa teks deskripsi adalah teks yang memaparkan suatu objek atau keadaan secara jelas sehingga pembaca seolah-olah mendengar, melihat, atau merasakan hal yang dipaparkan oleh penulis. Deskripsi adalah pemaparan atau gambaran dengan kata-kata secara jelas dan terperinci. Dengan adanya pendeskripsian, maka pembaca ataupun pendengar seolah-olah melihat atau mendengar sendiri apa yang disampaikan oleh pembicara atau penulis. Jadi dapat dikatakan bahwa teks deskripsi adalah teks yang menggambarkan suatu objek sehingga pembaca seolah-olah dapat melihat, mendengar, dan ikut merasakan hal-hal yang ditulis oleh pengarang.

Keterampilan menulis teks deskripsi membutuhkan keterampilan membaca pemahaman, karena kedua keterampilan tersebut memiliki hubungan ynag sangat erat. Berdasarkan peninjauan hasil belajar siswa kelas VII SMP Negeri 1 Bonjol, sebagian siswa beranggapan bahwa keterampilan menulis teks deskripsi itu sulit. Pernyataan tersebut dikarenakan oleh beberapa faktor, yaitu sebagai berikut: pertama, siswa kurang mengusai tentang teks deskripsi. Kedua, siswa kurang mampu mengidentifikasi struktur teks deskripsi. Ketiga, siswa kesulitan dalam mengembangkan isi teks deskripsi. Keempat, siswa kesulitan dalam pemilihan kosakata. Dari keempat permasalahan tersebut terbukti bahwa latihan siswa dalam 
menulis teks deskripsi berkisar antara 60-75. Sementara itu, KKM yang ditetapkan untuk mata pelajaran bahasa Indonesia adalah 78 .

Tujuan penelitian ini untuk mendeskripsikan beberapa hal. Pertama, mendeskripsikan keterampilan membaca pemahaman teks deskripsi pada siswa kelas VII SMP Negeri 1 Bonjol. Kedua, mendeskripsikan keterampilan menulis teks deskripsi siswa kelas VII SMP Negeri 1 Bonjol. Ketiga, menjelaskan adakah hubungan hubungan antara keterampilan membaca pemahaman teks deskripsi dengan keterampilan menulis teks deskripsi siswa kelas VII SMP Negeri 1 Bonjol.

\section{METODE}

Jenis penelitian ini termasuk penelitian kuantitaif. Dikatakan penelitian kuantitaif karena data yang diperoleh berupa angka, yaitu skor keterampilan membaca pemahaman dan skor keterampilan menulis. Hal ini sependapat dengan Arikunto (2010), penelitian kuantitatif banyak dituntut menggunakan angka, mulai dari pengumpulan, penafsiran terhadap data tersebut, serta penampilan hasilnya.

Metode yang digunakan dalam penelitian ini adalah metode korelasi. Metode deskriptif dengan pendekatan korelasi bertujuan mendeskipsikan, menganalisis, dan menginterpretasi data-data yang berupa angka kemudian menemukan ada tidaknya hubungan antara variabel yang satu dengan variabel yang lain. Metode korelasi bertujuan menemukan ada tidaknya hubungan, dan apabila ada, bearapa eratnya hubungan serta berarti tidaknya hubungan tersebut. Menurut Sugiyono (2011), penelitian korelasi bertujuan mengetahui tentang ada atau tidaknya dan kuat lemahnya suatu hubungan variabel bebas dengan variabel terikat dalam suatu objek atau subjek yang akan diteliti. Dalam penelitian ini rancangan penelitian korelasional digunakan untuk menghubungkan keterampilan membaca pemahaman teks deskripsi dengan keterampilan menulis teks deskripsi siswa kelas VII SMP Negeri 1 Bonjol.

Populasi dalam penelitian ini adalah seluruh siswa kelas VII SMP Negeri 1 Bonjol yang terdaftar pada tahun ajaran 2019/2020 yang berjumlah 247 orang siswa. Siswa tersebar dalam delapan kelas, yaitu VII.1-VII.8. Teknik pengambilan sampel yang digunakan adalah simple random sampling, yaitu sampel yang terdiri dai subsub sampel yang diambil secara acak, berdasarkan proporsi jumlah siswa per kelas.

Persentase sampel yang diambil dalam penelitian ini adalah $15 \%$ dari populasi per kelas. Hal ini sesuai dengan pendapat Arikunto (2010) yang menyatakan apabila subjek penelitian kurang dari 100, lebih baik diambil semuanya, tetapi jika jumlah subjek penelitian besar, dapat diambil antara $10-15 \%$ atau $20-25 \%$ atau lebih. Dengan demikian, sampel yang diambil dalam penelitian ini adalah 38 orang siswa.

Instrumen yang dilakukan dalam penelitian ini adalah tes. Tes digunakan untuk mengetahui kemampuan siswa dalam keterampilan membaca pemahaman teks deskripsi dan keterampilan menulis teks deskripsi siswa kelas VII SMP Negeri 1 Bonjol. Bentuk tes yang dilakukan adalah tes objektif yang digunakan untuk mengukur keterampilan membaca pemahaman teks deskripsi siswa kelas VII SMP negeri 1 Bonjol dan tes unjuk kerja yang digunakan untuk mengukur keterampilan menulis teks deskripsi siswa kelas VII SMP Negeri 1 Bonjol. Untuk, analisis data uji hipotesis menggunakan Korelasi Bivariate Pearson dengan SPSS 20. 


\section{HASIL}

1. Keterampilan Membaca Pemahaman Teks Deskripsi Siswa Kelas VII

SMP Negeri 1 Bonjol

Berdasarkan hasil penelitian dan hasil analisis data, diketahui bahwa keterampilan membaca pemahaman siswa kelas VII SMP Negeri 1 Bonjol dikelompokkan menjadi tiga kategori, yaitu baik sekali, baik dan lebih dari cukup. Nilai rata-rata keterampilan membaca pemahaman siswa kelas VII SMP Negeri 1 Bonjol adalah 81,65 dengan tingkat penguasaan $(76-85 \%)$ berada pada kualifikasi baik pada skala 10. Beradasarkan dari nilai rata-rata yang diperoleh dapat diakatakan sebagian besar siswa sudah mampu memhami isi teks yang dibaca. Hal ini terlihat pada nilai rata-rata yang diperoleh oleh siswa.

Indikator yang paling dikuasai siswa adalah indikator menentukan isi teks dengan nilai rata-rata 80,56 dengan tingkat penguasaan $(76-85 \%)$ berada pada kualifikasi baik pada skala 10. Berdasarkan dari nilai rata-rata yang diperoleh dapat dikatakan sebagian besar siswa sudah mulai mampu memahami isi teks yang dibaca. Hal ini terlihat dari nilai yang diperoleh siswa dengan rata-rata berada pada kualifikasi baik.

Penguasaan siswa yang paling rendah adalah pada indikator memahami kosakata atau diksi. Nilai rata-rata siswa adalah 72,89 dengan tingkat penguasaan (66-75\%) berada pada kulaifikasi lebih dari cukup. Berdasarkan pada nilai rata-rata tersebut dapat dikatakan bahwa siswa belum mampu memahami kosakata atau diksi. Hal ini terlihat dari nilai rata-rata yang diperoleh siswa pada kualifikasi lebih dari cukup.

Berdasarkan pembahasan tersebut, dapat disimpulkan bahwa nilai keterampilan membaca pemahaman teks deskripsi siswa kelas VII SMP Negeri 1 Bonjol masih berada pada kualifikasi baik. Oleh karena itu, secara umum siswa bisa dikatakan sudah memahami mengenai isi, struktur, dan diksi melalui kegiatan membaca pemahaman teks deskripsi. Dengan demikian siswa harus tetap meningkatkan keterampilan membaca pemahaman teks deskripsi yang dikuasai. Hal ini sejalan dengan pendapat Agustina (2008) mengemukakan bahwa tujuan membaca adalah untuk menangkap isi atau makna dari gagasan-gagasan yang terdapat dalam bacaan. Hal tersebut sependapat dengan pelaksanaan tes objektif yang digunakan untuk mengukur keterampilan membaca pemahaman siswa kelas VII SMP Negeri 1 Bonjol, dalam pelaksanaan tes tersebut sebagian besar siswa sudah melibatkan proses berpikir dalam menganalisis setiap butir soal yang diberikan.

\section{Keterampilan Menulis Teks Deskripsi Siswa Kelas VII SMP Negeri 1 Bonjol}

Berdasarkan hasil penelitian analisis data, didapatkan bahwa keterampilan menulis teks deskripsi siswa kelas VII SMP Negeri 1 Bonjol dikelompokkan menjadi tiga bagian, yaitu kategori baik sekali, baik, lebih dari cukup. Keterampilan menulis teks deskripsi siswa dikategorikan baik dengan nilai rata-rata 78,58 yang berada pada rentangan $76-85 \%$ pada skala 10 . Hal ini dikarenakan siswa kurang mampu menuangkan ide, pikiran, dan gagasan ke dalam bentuk tulisan. Keterampilan menulis teks deskripsi siswa dikategorikan baik.

Analisis data keterampilan menulis teks deskripsi siswa kelas VII SMP Negeri 1 Bonjol, menunjukkan rata-rata hitung dari ketiga indikator, isi teks berada pada kategori baik, stuktur teks berada pada kategori baik, dan pemilihan diksi berada pada kategori lebih dari cukup. Dari analisis tersebut, kesalahan yang paling banyak 
dilakukan oleh siswa ialah pemilihan diksi yang kurang tepat dengan nilai rata-rata 68,75 yang berada pada rentangan $66-75 \%$. Sementara itu, kesalahan yang paling sedikit dilakukan siswa terdapat pada indikator satu, yaitu pada isi teks dengan nilai rata-rata 88,75 karena sebagian besar siswa telah mampu menulis teks deskripsi.

Pemilihan diksi adalah kesalahan yang paling banyak dilakukan siswa yaitu pada indikator ketiga dengan nilai rata-rata 68,75. Berdasarkan analisis yang dilakukan, tampak bahwa pada penulisan teks deskripsi siswa masih kurang mampu memahami penjelasan terhadap ide, gagasan, dan pikiran yang akan disampaikan. Selain itu, siswa juga kesulitan memilih kosakata yang tepat.

Berdasarkan analisis penilaian teks deskripsi siswa, dapat disimpulkan bahwa keterampilan menulis teks deskripsi siswa, terutama pada indikator penggunaan kosakata atau pemilihan diksi sebagai alat untuk memberikan keyakinan kepada pembaca bahwa topik yang ditulis adalah topik yang penting untuk dibahas dinyatakan tidak tercapai. Hal ini juga telah diuaraikan pada bagian latar belakang. Pada tulisan teks deskripsi siswa kesulitan dalam menuangkan ide, gagasan, dan pikiran ke dalam bentuk tulisan. Pada penulisan teks deskripsi siswa tidak mampu menggunakan kebahasaan yang baik dan benar. Siswa hanya menulis teks deskripsi dengan memberikan pernyataan yang sangat umum dan ini terbukti bahwa siswa tidak memahami apa yang seharusnya diungkapkan ke dalam bentuk tulisan.

Ketidakberhasilan ini disebabkan karena lemahnya indikator penggunaan diksi. Selain itu, ketidakberhasilan siswa meyakinkan pembaca juga dipengaruhi oleh penggunaan afiks, penggunaan pronominal, penggunaan frasa yang tidak sesuai dengan ejaan bahasa Indonesia yang baik dan benar. Pemberian fakta atau contoh untuk memperkuat isi yang masih kurang jelas. Kekurangan yang ditemukan pada bagian struktur yang sangat berpengaruh terhadap pencapaian isi teks yang dikemukakan masih belum jelas dan kadang tidak relevan dengan ide utama. Hal ini pada akhirnya juga berakibat pada pemberian fakta pendukung (bukti dan contoh) untuk memperkuat isi teks.

Dalam sebuah teks, kejelasan penggunaan diksi pada teks deskripsi dapat dikatakan sebagai hal pertama yang harus dilakukan secara jelas. Hal ini disebabkan karena bagian pembuka ini merupakan bagian penentu untuk kejelasan isi dan ketercapaian tujuan penulisan. Oleh karena ketidakjelasan ide pada bagian pendahuluan, maka dapat dipastikan bagian berikutnya yaitu tubuh (body) yang terdiri dari beberapa paragraf, yang memaparkan argument-argumen dalam bentuk penjelasan dengan contoh, fakta, bertujuan untuk mendukung dan mengembangkan isi yang menyajikan unsur kebahasaan tentang keadaan, peristiwa, tempat atau benda juga tidak akan dapat diuraikan dengan baik. Jadi, dapat disimpulkan bahwa isi merupakan bagian pengontrol pada teks deskripsi sehingga ide penulis dapat disampaikan secara terorganisir dan tidak bertele-tele. Oleh karena itu, agar isi teks deskripsi dapat memberikan informasi tentang suatu objek, maka siswa atau penulis harus mampu memberikan sebuah ide yang dapat diinterpretasikan dengan baik dan diperkuat dengan fakta-fakta yang ada.

\section{PEMBAHASAN}

Berdasarkan hasil analisis data penelitian, ditemukan adanya korelasi antara keterampilan membaca pemahaman teks deskripsi dengan keterampilan menulis teks deskrispsi siswa kelas VII SMP Negeri 1 Bonjol. Hal ini ditunjukkan dengan hasil dari uji hipotesis menggunakan Analisis Korelasi Bivariate Pearson dengan SPSS yang menunjukkan bahwa nilai $t_{\text {hitung }}$ lebih besar $t_{\text {tabel }}$. Kesimpulan ini juga didukung oleh fakta 
hasil penelitian bahwa keterampilan membaca pemahaman teks deskripsi siswa berada pada kualifikasi baik, sedangkan keterampilan menulis teks deskripsi siswa berada pada kualifikasi baik dari keseluruhan indikator. Hal ini tidak jauh berbeda dengan penelitian yang dilakukan oleh Sari dkk. () Bahwa semakin baik tingkat pemahaman bacaan siswa maka akan semakin baik kemampuan dalam menulis. Hanya saja, bedanya penelitian ini pada kemampuan menulis teks laporan hasil observasi sedangkan dalam penelitian yang dilakukan fokus pada keterampilan menulis teks deskripsi.

Berikut ini penjelasan hubungan keterampilan membaca pemahaman teks deskripsi dengan keterampilan menulis teks deskripsi ketiga indikator. Pertama, hubungan keterampilan memaca pemahaman dengan keterampilan menulis teks deskripsi siswa kelas VII SMP Negeri 1 Bonjol indikator isi teks. Dilihat secara keseluruhan, siswa mampu memahami isi teks deskripsi yang disusun dengan pola kausalitas. Siswa mampu membedakan makna keenam unsur tersebut dengan baik. Siswa menentukan dengan tepat hubungan antar kalimat yang menyatakan pola hubungan sebab-akibat. Oleh karena itu, dapat dikatakan siswa memiliki tingkat pemahaman yang tinggi terhadap isi teks deskripsi yang dibacanya. Selanjutnya, apabila dilihat dari keterampilan menulis teks deskripsi indikator isi teks, terlihat bahwa mengaplikasikan pemahamannya terhadap teks deskripsi ke dalam bentuk tulisan dengan baik. Sebagian siswa memperoleh nilai sempurna, yang artinya siswa menulis teks deksripsi dengan isi yang tepat. Siswa menjelaskan proses terjadinya fenomena dengan tepat sesuai dengan konteks yang diberikan.

Kedua, hubungan keterampilan membaca pemahaman dengan keterampilan menulis teks deskripsi siswa kelas VII SMP Negeri 1 Bonjol indikator struktur teks. Dilihat secara keseluruhan, siswa mampu menentukan struktur teks deskripsi yang berupa identifikasi fenomena, rangkaian kejadian, ulasan. Siswa mampu menentukan dan membedakan ketiga struktur teks deskripsi yang dibacanya. Siswa menentukan sruktur teks dengan tepat sesuai dengan konteks yang diberikan. Hanya beberapa siswa yang mendapatkan nilai cukup dan yang lainnya berkisar antara baik hingga sempurna. Oleh karena itu, dapat dikatakan siswa memiliki tingkat pemahaman yang tinggi terhadap struktur teks deskripsi yang dibacanya. Selanjutnya, apabila dilihat dari keterampilan menulis teks deskripsi indikator struktur teks, terlihat bahwa siswa sudah mampu mengaplikasikan pemahamannya terhadap struktur teks deskripsi ke dalam bentuk tulisan. Sebagian siswa memperoleh nilai sempurna, yang artinya siswa mampu menulis teks deskripsi dengan struktur yang lengkap. Siswa menuliskan struktur teks deskripsi sesuai konteks yang diberikan. Siswa juga menuliskan identifikasi fenomena sebagai struktur awal teks deskripsi. Bagian rangkaian kejadian juga sudah dikembangkan dengan jelas. Pada bagian ulasan, siswa menuliskan penilaian tentang konsekuensi atas kejadian yang dipaparkan. Hanya beberapa siswa yang mendapatkan nilai cukup yang artinya siswa belum menuliskan struktur berita dengan lengkap. Ada siswa yang menulis teks deskripsi tanpa struktur identifikasi fenomena, menulis teks deskripsi tanpa struktur ulasan, bahkan ada yang hanya menulis bagian rangkaian kejadian saja. Jadi, dapat disimpulkan bahwa adanya korelasi yang signifikan antara keterampilan membaca pemahaman teks deskripsi dengan keterampilan menulis teks deskripsi indikator struktur teks dengan kualifikasi baik.

Selanjutnya, hubungan keterampilan membaca pemahaman teks deskripsi dengan keterampilan menulis teks deskripsi siswa kelas VII SMP Negeri 1 Bonjol indikator diksi. Dilihat secara keseluruhan, siswa memahami penggunaan diksi yang tepat. Hampir sebagian siswa memperoleh nilai sempurna dalam memahami diksi dan sebagian yang lain berkisar antara hampir cukup hingga baik sekali. Oleh karena itu, dapat dikatakan 
siswa memiliki tingkat pemahaman yang baik terhadap penggunaan diksi yang dibacanya. Selanjutnya, apabila dilihat dari keterampilan menulis teks deskripsi indikator diksi, terlihat bahwa siswa masih kurang mampu mengaplikasikan pemahaman terhadap penggunaan diksi dibacanya ke dalam bentuk tulisan. Siswa kesulitan dalam menggunakan pilihan kata yang tepat.

Banyak siswa yang menuliskan fenomena dengan tidak jelas. Nilai yang diperoleh siswa pada umumnya berkisar antara hampir cukup hingga lebih dari cukup. Jadi, berdasarkan indikator diksi, belum terlihat hubungan yang positif antara keterampilan membaca pemahaman teks deskripsi dengan keterampilan menulis teks deskripsi. Oleh karena itu, siswa memerlukan latihan menulis dalam pembelajaran ini secara terbimbing (Hasibuan, 2017). Berdasarkan pembahasan tersebut, disimpulkan adanya korelasi antara keterampilan membaca pemahaman teks deskripsi dengan keterampilan menulis teks deskripsi siswa kelas VII SMP Negeri 1 Bonjol.

Membaca pemahaman banyak sekali manfaat yang diperoleh untuk meningkatkan keterampilan menulis yaitu membaca memperluas wawasan dan pengetahuan, meningkatkan dan melatih daya pikir serta membaca dapat memperkaya kosakata sehingga mudah untuk menuangkan ide-ide dan gagasan dalam sebuah tulisan khususnya dalam menulis teks eksplanasi (Manullang \& Lubis, 2017; Sari dkk., 2020; Hermanudin dkk., 2019). Semakin sering siswa membaca teks deskripsi, maka hasil menulis teks deskripsi juga semakin baik.

\section{KESIMPULAN DAN SARAN}

Hasil penelitian ini menunjukkan bahwa terdapat hubungan yang signifikan antara keterampilan membaca pemahaman teks deskripsi dengan keterampilan menulis teks deskripsi siswa kelas VII SMP Negeri 1 Bonjol. Dengan demikian, dapat diketahui bahwa semakin tinggi dan baik keterampilan membaca pemahaman siswa akan semakin tinggi dan baik pula tingkat keterampilan menulis teks deskripsi siswa.

Berdasarkan hasil penelitian ini, diharapkan kepada guru bahasa Indonesia untuk meningkatkan keterampilan membaca pemahaman teks deskripsi dan keterampilan menulis teks deskripsi siswa. Kepada siswa SMP Negeri 1 Bonjol diharapkan dapat menyadari betapa pentingnya keterampilan membaca dan keterampilan menulis. Khususnya keterampilan membaca pemahaman teks deskripsi dan keterampilan menulis teks deskripsi. Selanjutnya, kepada guru SMP Negeri 1 Bonjol, diharapkan untuk senantiasa memberikan kegiatan membaca pemahaman dan menulis secara berkala sehingga hasil belajar siswa dalam setiap kompetensi dasar tercapai dengan maksimal.

\section{DAFTAR PUSTAKA}

Agustina. (2008). Pembelajaran Keterampilan Membaca. Padang: IKIP Padang.

Amrolani, A., Muslihah, N. N., \& Noermanzah, N. (2014). Peningkatan Kemampuan Menulis Karangan Deskripsi melalui Teknik Imajinasi Siswa Kelas IV SD Negeri 51 Lubuklinggau. Jurnal Perspektif Pendidikan, 8(1), 1-2.

Anggriani, V. (2016). Hubungan Kemampuan Membaca Pemahaman dengan Kemampuan Menulis Paragraf Eksposisi Siswa Kelas X SMA N 9 Padang. Padang: STKIP PGRI Sumatera. http://jim.stkip-pgri-sumbar.ac.id/. Diunduh pada 10 Februari 2020. 
Arikunto, S. (2010). Prosedur Penelitian: Suatu Pendekatan Praktek. Jakarta: Rineka Cipta.

Haryati, H. (2018). Peningkatan Motivasi dan Kemampuan Menulis Teks Deskripsi melalui Pendekatan Proses Siswa Kelas VII Smp Negeri 5 Magelang. Diksi, 25(2). doi:10.21831/diksi.v25i2.15665

Hasibuan, S. (2017). Meningkatkan Kemampuan Menulis Karangan Deskripsi Dengan Metode Latihan Terbimbing Menggunakan Gambar di SMAN 4 Pekanbaru. GERAM, 5(2), 1-6. doi:10.25299/geram.2017.vol5(2).467

Hermanudin, Suhartono, Suryadi, \& Noermanzah. (2019). Improvement of Reading Comprehension Ability by Using Core Models of Class VII a Students of SMP Negeri 10 Bengkulu Tengah. International Journal of Scientific and Technology Research, 8(12).

Karto, Suhartono, Susetyo, Noermanzah, Maisarah, I. (2019). The Differences Ability in Writing Descriptive Texts by Using Chain Writing and Conventional Methods. International Journal of Scientific \& Technology Research, 8(10), 2718.

Khasanah, A. \& Cahayani, I. (2016). Peningkatan Kemampuan Membaca Pemahaman dengan Strategi Question Answer Relationships (QAR) pada Siswa Kelas V Sekolah Dasar. Jurnal Pedagogik Pendidikan Dasar, 4(2).

Kusumaswarih, K. K. (2018). Strategi Kesantunan Berbahasa dalam Pembelajaran Bahasa Indonesia. Belajar Bahasa, 3(2). doi:10.32528/bb.v3i2.1583

Manullang, Y. N., \& Lubis, M. (2017). Hubungan Kemampuan Membaca Pemahaman dengan Kemampuan Menulis Ringkasan oleh Siswa Kelas VIII SMP Negeri 1 Medan Tahun Pembelajaran 2017/2018. Kode: Jurnal Bahasa, 6(4). doi:10.24114/kjb.v6i4.10836

Muttaqillah, M. (2019). Peningkatan Kemampuan Menulis Eksposisi Melaui Kegiatan Menulis Berita Siswa Kelas X MA Pembangunan UIN Jakarta. Pena Literasi, 2(1), 18. doi:10.24853/pl.2.1.177-188

Noermanzah, N. (2013). Pelaksanaan Pembelajaran Bahasa Indonesia Kelas VII SMP Negeri se-Kota Lubuklinggau Tahun Ajaran 2012/2013. Jurnal Perspektif Pendidikan, $\quad 7(2), \quad$ 49-50. lubuklinggau.ac.id/index.php/JPP/article/view/370

Noermanzah, N., Abid, S., \& Aprika, E. (2018). Pengaruh Teknik Send a Problem terhadap Kemampuan Menulis Daftar Pustaka Siswa Kelas XI SMA Negeri 4 Lubuklinggau. Jurnal Kajian Bahasa, Sastra dan Pengajaran (KIBASP), 1(2), 172. https://doi.org/https://doi.org/10.31539/kibasp.v1i2.273

Novia, Tressyalina, \& Hafrison, M. Korelasi Keterampilan Membaca Pemahaman Teks Eksposisi dengan Keterampilan Menulis Teks Eksposisi Siswa Kelas X Sma Negeri 7 Padang. Jurnal Pendidikan Bahasa dan Sastra Indonesia, 6(2). 
Prayitni, E. T. (2014). Desain Pembelajaran Bahasa Indonesia dalam Kurikulum 2013. Jakarta: Bumi Aksara.

Rinawati, A., Mirnawati, L. B., \& Setiawan, F. (2020). Analisis Hubungan Keterampilan Membaca dengan Keterampilan Menulis Siswa Sekolah Dasar. Education Journal : Journal Educational Research and Development, 4(2), 8596. doi:10.31537/ej.v4i2.343

Sari, M.H., Susetyo, Noermanzah, Wardhana, D.E.C., Kusumaningsih, D. (2020). Understanding the Level of Students' Reading Comprehension Ability. Universal Journal of Educational Research, 8(5). https://doi.org/10.13189/ujer.2020.080521

Sari, Y., Ramadhan, S, \& Rasyid, Y. (2018). Hubungan antara Keterampilan Membaca Pemahaman dengan Keterampilan Menulis Teks Laporan Hasil Observasi Siswa Kelas X SMK Negeri 3 Padang. Jurnal Pendidikan Bahasa dan Sastra Indonesia, 7(3).

Semi. M. A. (2003). Dasar-Dasar Keterampilan Menulis. Bandung: Angkasa.

Sugiyono. (2011). Metode Penelitian Kuantitatif, Kualitatif dan R\&D. Bandung: Afabeta.

Tarigan, H. G. (2008). Menulis sebagai Suatu Keterampilan Berbahasa. Bandung: Angkasa.

Umaya, N. M. (2017). Model Penemuan Konsep Berbasis Teks pada Pembelajaran Sastra. Indonesian Language Education and Literature, 2(2), 163. doi:10.24235/ileal.v2i2.1292 